\title{
Quality Of Birth Certificate Management Services in the Department of Population and Civil Registration Bojonegoro District
}

\author{
Ahmad Suprastiyo \\ The Faculty of Social and Political Sciences, University of Bojonegoro
}

\begin{abstract}
Improving the quality of public services is an important concern for the government, this is evidenced by the enactment of Law Number 25 of 2009 concerning Public Services. Services maintenance of a birth certificate is an administrative services provided by the government to its citizens. However, the reality in the field of birth certificate management services at the Population and Civil Registration Service Office is not yet in accordance with the expectations of the community in getting public services, this can be explained in birth certificate services that often occur delays, so applicants have to wait two to three days. This study aims to identify and explain services processing of birth certificates at the Office of Population and Civil Registration. This type of research is descriptive research with a qualitative approach. Determination of informants using purposive and incendental sampling. Data analysis uses data collection, data reduction, data display, and conclusion drawing / verifying. The results of the study based on community satisfaction survey showed that service quality management of a birth certificate get a good category .
\end{abstract}

Keywords:- Birth Certificate, Quality, Service.

\section{INTRODUCTION}

Public service is an activity or a series of activities in order to fulfill service needs in accordance with statutory regulations for every citizen and resident of goods, services and / or administrative services provided by public service providers. Public services provided by the government or effective corporations can strengthen democracy and human rights, promote economic prosperity, social cohesion, reduce poverty, improve environmental protection, be wise in the use of natural resources, deepen trust in government and public administration. The prime service quality is the service that brings the government closer to the community. This is realized by knowing and analyzing various problems faced by the community, to then create an efficient service strategy.

Improving the quality of public services is an important concern for the government, this is evidenced by the enactment of Law Number 25 of 2009 concerning Public Services and Regulation of the Minister of State Apparatus Empowerment and Bureaucratic Reform
Number 14 of 2017 concerning Guidelines for Community Satisfaction Surveys on Public Service Delivery. The Department of Population and Civil Registration of Bojonegoro Regency is one of the implementers of public administration services in the East Java region. This population service includes population registration and civil registration. Resident registration includes the management of Family Cards, Electronic Identity Cards, transfer documents, and Child Identity Cards, while civil registration includes processing birth certificate quotes, excerpts of death certificates, quotations of divorce certificates, recording children's confessions and child legalization, recording name changes, and recording. change of citizenship.

At the time of the initial observation at the Population and Civil Registration Office of Bojonegoro Regency, there were several complaints from the public about service performance in managing birth certificate documents, family cards, and electronic identity cards. Especially in birth certificate services there are often delays, so applicants have to wait two to three days. Based on these problems, it is known that the Department of Population and Civil Registration of Bojonegoro Regency has not provided services in accordance with the expectations and desires of the community.

\section{RESEARCH METHODS}

This type of research is a descriptive study with a qualitative approach. The focus of this research is requirements, systems, mechanisms and procedures, completion time, costs / rates, product specifications for types of services, competency of executors, behavior of executors, handling of complaints, suggestions and input, means. Retrieval of research informants using purposive and incendental sampling techniques, in the research process inventory primary data sources were 50 informants. Sources of data used are primary data sources and secondary data by means of observation, questionnaires and documentation. In analyzing using interactive data analysis techniques Model miles and Huberman, who argued that "activities in qualitative data analysis are carried out interactively and continue to completion. Activities in data analysis, namely data reduction, data display and conclusion drawing / verifying "(in Sugiyono 2011 : 404). 


\section{RESULTS AND DISCUSSION}

The Public Satisfaction Survey is carried out in accordance with the provisions in the Regulation of the Minister of Administrative Reform and Bureaucratic Reform Number 14 of 2017 concerning Guidelines for the Survey of Community Satisfaction on Public Service Delivery. The previous regulations were deemed nonoperational and required technical elaboration in their implementation. So it needs to be adjusted to an applicable survey method and easy to implement. In addition, this Regulation is intended to provide clear and firm directions and guidelines for public service providers.

In the Regulation of the Minister of State Apparatus Empowerment and Bureaucratic Reform Number 14 of 2017, it is stated that the Community Satisfaction Survey aims to measure the level of community satisfaction as service users and improve the quality of public service delivery. With goals: $m$ endorong participation mobi tion of a service users in assessing the performance of service providers , $\mathrm{m}$ endoron $\mathrm{g}$ providers of care for meningk atkan quality of public services, $m$ endorong service providers become more innovative in me nyelenggarakan public services, $m$ engukur kecenderun gan community satisfaction levels against public service. According to Wyckcof and Lovelock in their book, which is quoted and translated by Fandy Tjiptono (2005: 60), there are two main factors that affect service quality, namely respected service and perceived service.

\section{Requirements}

Requirements are requirements that must be met in administering a type of service, both technical and administrative requirements. The data from the questionnaire results are as shown in table 1 below:

\begin{tabular}{|c|c|c|c|}
\hline No & Respondents & Count & Percentage (\%) \\
\hline 1 & It is not in accordance with & 1 & 2 \\
\hline 2 & less suitable & 9 & 18 \\
\hline 3 & Corresponding & 28 & 56 \\
\hline 4 & Perfectly fit & 12 & 24 \\
\hline & Amount & 50 & 100 \\
\hline
\end{tabular}

Table 1:- Respondents' responses to requirements Source: Primary Data Processed

Respondents who answered point 1 were $2 \%$, while those who answered point 2 were $18 \%$, then those who answered point 3 were $56 \%$, and those who answered point 4 were $24 \%$.

\section{Systems, mechanisms and procedures}

Systems, mechanisms and procedures are procedures for services performed for service providers and recipients, including complaints. The questionnaire result data is as follows:

\begin{tabular}{|c|c|c|c|}
\hline No & Respondents & Count & Percentage (\%) \\
\hline 1 & not easy & 2 & 4 \\
\hline 2 & not easy & 9 & 18 \\
\hline 3 & easy & 24 & 48 \\
\hline 4 & Very easy & 15 & 30 \\
\hline & Amount & 50 & 100 \\
\hline
\end{tabular}

Table 2:- Response Systems, mechanisms and procedures Source: Primary Data Processed

Respondents who answered point 1 were $4 \%$, while those who answered point 2 were $18 \%$, then those who answered point 3 were $48 \%$, and those who answered point 4 were $30 \%$.

\section{Turnaround time}

Turnaround time is the time required to complete the entire service process of each type of service. The questionnaire result data is as follows:

\begin{tabular}{|c|c|c|c|}
\hline No & Respondents & Count & Percentage (\%) \\
\hline 1 & not fast & 0 & 0 \\
\hline 2 & less fast & 2 & 4 \\
\hline 3 & fast & 48 & 96 \\
\hline 4 & Very fast & 0 & 0 \\
\hline & Amount & 50 & 100 \\
\hline
\end{tabular}

Table 3:- Response w ime settlement

Source: Primary Data Processed 
It can be seen that respondents who answered point 1 were as much as $0 \%$, while those who answered point 2 were as much as $0 \%$, then those who answered point 3 were $4 \%$, and those who answered point 4 were as much as $96 \%$.

\section{Fees / Rates}

Fees / tariffs are fees charged to service recipients in managing and / or obtaining services from the operator, the amount of which is determined based on an agreement between the organizer and the community. The data from the questionnaire results are as shown in table 4 below:

\begin{tabular}{|c|c|c|c|}
\hline No & Respondents & Count & Percentage (\%) \\
\hline 1 & Very expensive & 0 & 0 \\
\hline 2 & Quite expensive & 0 & 8 \\
\hline 3 & Cheap & 4 & 92 \\
\hline 4 & Free & 46 & 100 \\
\hline & Amount & 50 & \\
\hline
\end{tabular}

Table 4:- Cost / Tariff response

Source: Primary Data Processed

Respondents who answered point 1 were $0 \%$, while those who answered point 2 were $0 \%$, then those who answered point 3 were $8 \%$, and those who answered point 4 were $92 \%$.

\section{Product Specifications Type of Service}

Product Specifications Type of Service is the result of services provided and received in accordance with the stipulated provisions . This service product is the result of each type of service specification. The data from the questionnaire results are as shown in table 5 below:

\begin{tabular}{|c|c|c|c|}
\hline No & Respondents & Count & Percentage (\%) \\
\hline 1 & it is not in accordance with & 0 & 0 \\
\hline 2 & not suitable & 8 & 62 \\
\hline 3 & corresponding & 31 & 22 \\
\hline 4 & Very suitable & 11 & 100 \\
\hline & Amount & 50 & 62 \\
\hline
\end{tabular}

Table 5:- Product Responses Specifications Type of Service

Source: Primary Data Processed

Respondents who answered point 1 were $0 \%$, while those who answered point 2 were $16 \%$, then those who answered point 3 were $62 \%$, and those who answered point 4 were $22 \%$.

\section{Implementing Competencies}

Implementer competencies are abilities that must be possessed by executors including knowledge of skills and experience. The data from the questionnaire results are as shown in table 6 below:

\begin{tabular}{|c|c|c|c|}
\hline No & Respondents & Count & Percentage (\%) \\
\hline 1 & incompetent & 1 & 2 \\
\hline 2 & less competent & 4 & 8 \\
\hline 3 & competent & 36 & 12 \\
\hline 4 & Very competent & 9 & 100 \\
\hline & Amount & 50 & 18 \\
\hline
\end{tabular}

Table 6:- Implementing Competency Responses

Source: Primary Data Processed

Respondents who answered point 1 were $2 \%$, while those who answered point 2 were $14 \%$, then those who answered point 3 were $76 \%$, and those who answered point 4 were $8 \%$. 


\section{Implementing Behavior}

Implementing behavior is the attitude of officers in providing services. The data from the questionnaire results are as shown in table 7 below:

\begin{tabular}{|c|c|c|c|}
\hline No & Respondents & Count & Percentage (\%) \\
\hline 1 & disrespectful \& friendly & 1 & 2 \\
\hline 2 & Not polite \& friendly & 7 & 14 \\
\hline 3 & Polite and friendly & 38 & 76 \\
\hline 4 & Very polite and friendly & 4 & 8 \\
\hline & Amount & 50 & 100 \\
\hline
\end{tabular}

Table 7:- Implementing Behavior Responses

Source: Primary Data Processed

Respondents who answered point 1 were $2 \%$, while those who answered point 2 were $14 \%$, then those who answered point 3 were $76 \%$, and those who answered point 4 were $8 \%$.

Handling complaints, suggestions and input

Complaint handling, suggestions and input are the procedures for handling complaints and follow-up actions. The data from the questionnaire results are as shown in table 8 below:

\begin{tabular}{|c|c|c|c|}
\hline No & Respondents & Count & Percentage (\%) \\
\hline 1 & disrespectful \& friendly & 1 & 14 \\
\hline 2 & Not polite \& friendly & 38 & 76 \\
\hline 3 & Polite and friendly & 4 & 8 \\
\hline 4 & Very polite and friendly & 50 & 100 \\
\hline
\end{tabular}

Table 8:- Responses to handling complaints, suggestions and input Source: Primary Data Processed

Respondents who answered point 1 were $0 \%$, while those who answered point 2 were $30 \%$, then those who answered point 3 were $64 \%$, and those who answered point 4 were $6 \%$.

\section{Facilities and Infrastructure}

Means are anything that can be used as a means to achieve goals and objectives. Infrastructure is anything that is the main support for the implementation of a process (business, development, project). Facilities used for moving objects (computers, machines) and infrastructure for immovable objects (buildings). The data from the questionnaire results are as shown in table 9 below:

\begin{tabular}{|c|c|c|c|}
\hline No & Respondents & Count & Percentage (\%) \\
\hline 1 & Bad & 0 & 30 \\
\hline 2 & Enough & 15 & 64 \\
\hline 3 & Well & 32 & 6 \\
\hline 4 & Very good & 50 & 100 \\
\hline
\end{tabular}

Table 9:- Response to Facilities and Infrastructure

Source: Primary Data Processed

Respondents who answered point 1 were $0 \%$, while those who answered point 2 were $22 \%$, then those who answered point 3 were $68 \%$, and those who answered point 4 were $10 \%$. 
The value of each quality indicator of birth certificate processing is in table 10 below:

\begin{tabular}{|c|c|c|}
\hline No. & Service Indicators & Average value \\
\hline 1 & Requirements & 3.02 \\
\hline 2 & Systems, mechanisms and procedures & 3.04 \\
\hline 3 & Turnaround time & 3.96 \\
\hline 4 & Fees / Rates & 3.92 \\
\hline 5 & Product Specifications Type of Service & 3.06 \\
\hline 6 & Implementing Competencies & 2.90 \\
\hline 7 & Implementing Behavior & 2.76 \\
\hline 8 & Handling complaints, suggestions and input & 2.88 \\
\hline 9 & Facilities and infrastructure & 3.07 \\
\hline
\end{tabular}

Table 10:- Value of Quality Indicators of Birth Certificate Management Source: Primary Data Processed

\section{CONCLUSION}

Based on the results of research on the quality of birth certificate management services at the Bojonegoro Regency Population and Civil Registration Office, it is concluded that the Community Satisfaction Survey (SKM) on the quality of public services at the Bojonegoro Regency Population and Civil Registration Service Office can be assessed from 9 aspects of SKM Certificate Management Services Birth got a good category (3.07) .

\section{REFERENCES}

[1]. Sugiyono, 2011, Metode Penelitian Kuantitatif, Kualitatif dan R\&D. Bandung: Afabeta.

[2]. Tjiptono Fandy, 2005, Service, Quality and Saticfaction. Yogyakarta: Andi Offset.

[3]. Tjiptono Fandy, 2008. Service Management Mewujudkan Layanan Prima. Yogyakarta: Andi Offset

[4]. Undang-Undang Nomor 25 Tahun 2009 tentang Pelayanan Publik

[5]. Peraturan Menteri Pendayagunaan Aparatur Negara dan Reformasi Birokrasi Nomor 14 Tahun 2017 tentang Pedoman Penyusunan Survei Kepuasan Masyarakat 